\title{
Laboratory medicine and the identity change of veterinary medicine in Spain at the turn of the twentieth century
}

\section{José Manuel Gutiérrez García (*)}

${ }^{*}$ Associate Professor of History of Science, Faculty of Medicine, Universitat Autònoma de Barcelona, 08193 Bellaterra (Barcelona), Spain. JoseManuel.Gutierrez@uab.cat

Dynamis

[0211-9536] 2010; 30: 239-260
Fecha de recepción: 4 de agosto de 2008

Fecha de aceptación: 13 de julio de 2009

SUMMARY: 1.-Veterinary medicine: A discipline forced to reinvent itself. 2.-The role of veterinary medicine in public health in Spain: A conflict of professional interests. 3.-The laboratory and the reinvention of veterinary medicine in the cognitive order. 4.-The laboratory and the reinvention of veterinary medicine in the social order. 5.-Conclusions.

ABSTRACT: This paper analyses the impact of laboratory medicine on veterinary medicine in Spain at the turn of the twentieth century. It is considered from a perspective that places the laboratory at the centre of a strategy for introducing the ideal of progress into veterinary medicine at a sensitive moment in its history. In the adverse context created by the steady replacement of horses - the principal recipients of veterinary care- by motor vehicles, an awareness grew that the time had come to reinvent the profession. The arrival of experimental veterinary medicine, especially the area linked to bacteriological laboratories, opened the door to explore new prospects for the future and became one of the bases for the discipline's modernisation. A new professional was envisaged to attain this objective, the "scientific laboratory veterinarian», whose knowledge would be based on experimentation and who would master highly specialised technical skills. This vision of a profession in search of prestige would bring to light conflicting interests among the different healthcare professions and would emphasise the importance of adopting patterns of behaviour that led to identification of these new veterinary surgeons with the elite of society.

KEY WORDS: Veterinary medicine, laboratories, microbiology, 20th century, Spain.

PALABRAS CLAVE: Medicina veterinaria, laboratorio, microbiología, siglo XX, España. 


\section{Veterinary medicine: A discipline forced to reinvent itself $\left(^{*}\right)$}

In the course of the nineteenth century, under the influence of positivism, a profound modernisation of medical science took place. In the context of this cultural phenomenon, any knowledge not drawn from experience lacked scientific validity and all $a$ priori and universal absolutes were rejected ${ }^{1}$. In medicine, positivism imposed objectivisation of the facts of the clinical case as the only scientific reality and this was the guiding idea which was to play a decisive role in transforming, in the language of the day, the old veterinary medicine into a modern science.

Naturally, this development had a series of technical implications. At a time when experience and induction had emerged as the dominant methods in science, instruments and laboratories were to shape the new, unceasing flood of science ${ }^{2}$.

However, the great renewal of ideas and methods in medical disciplines from the last third of the nineteenth century on was not mirrored immediately in Spanish veterinary science. Instead, at the turn of the twentieth century the vast majority of vets were still rooted in the customs of old ones, by centring on forging and fitting horseshoes, purging and blood-letting. What is more, all this was circumscribed to their most lucrative patients - horses - whose numbers were beginning to dwindle in addition to lose value as horsepower was steadily being replaced by motor vehicles.

The leaders of North American veterinary medicine met this challenge by adopting strategies based on determining the value which citizens attached to their animals. This enabled them to know which species were appreciated most and were most likely to require an expert's intervention. This implied reorienting the profession towards public health issues and productive animals ${ }^{3}$.

$\left(^{*}\right)$ This article is a result of the research project HUM2006-12278-C03-03 funded by the Spanish Ministry of Education and Science.

1. Bynum, William F. Science and the practice of medicine in the nineteenth century. Cambridge: Cambridge University Press; 1994.

2. Sánchez Ron, José Manuel; Lafuente, Antonio. El laboratorio de España: la Junta para Ampliación de Estudios e Investigaciones Científicas (1907-1939). Madrid: Sociedad Estatal de Conmemoraciones Culturales, Residencia de Estudiantes; 2007.

3. Jones, Susan D. Valuing animals. Veterinarians and their patients in modern America. Baltimore: The Johns Hopkins University Press; 2003, p. 37-38. 
In Europe, the motorisation of society and the subsequent decline in the number and value of horses left veterinary medicine at the same crossroads as in the USA. However, there is a lack of studies assessing the impact and the strategies adopted on this side of the Atlantic. In the case of Spain, it does not seem appropriate to use the annual animal censuses published by the Department of Agriculture. According to sources at the time, due to the lack of budget, the only basis for these data were the statistics from the previous year whose figures «however official, will be one more fiction in this country» ${ }^{4}$.

Yet, the replacement of animal-power by motor vehicles was a global phenomenon which also affected Spain. For example, in 1914 a report in a specialised journal warned about «five fateful words: the end of the horse» ${ }^{5}$.

This delicate situation forced veterinarians to explore new ambits and made some leading practitioners aware that the time had come to reinvent their profession ${ }^{6}$. These promoters of this veterinary science's reform mostly belonged to the Cuerpo de Inspectores de Higiene Pecuaria y Sanidad Veterinaria (Inspectorate of Livestock Hygiene and Veterinary Health) that had been created by Royal Decree on October 25, 1907 with the main objective of monitoring the state of livestock health in the forty-nine provinces of Spain as well as in its ports and frontiers. The entrance examination (which was almost entirely on microbiology matters) to fill the sixty-four vacancies was held in September 1909 and the civil servants took up their positions from February 1910. The

4. Doctor mínimo. Retablillo profesional. Revista de Higiene y Sanidad Veterinaria. 1913; 3: 729-732 (729).

5. El caballo y el automóvil. Revista de Higiene y Sanidad Veterinaria. 1914; 4: 27. The author of this study has not been able to find data to illustrate this phenomenon from a quantitative point of view (in any of its levels, namely, national, regional or local) for the case of Spain. Therefore, the statement is based on notes appearing in professional journals with their authors' personal opinions or on statistics taken from other countries, mainly France. By way of example see: ¿Desterrará el automóvil al caballo? Revista Veterinaria de España. 1910; 5: 40. Sanz Egaña, Cesáreo. La evolución de la veterinaria. Revista Veterinaria de España. 1912; 7: 522-525. Progreso de la fabricación de automóviles. Revista Veterinaria de España. 1912; 7: 536.

6. In 1912, a note in a specialed journal warned that «no-one must forget that today veterinary medicine in Spain stands at the most dangerous point in its development» and that the time had come for «scientific and economic regeneration» of the discipline. Veterinarios: ¡A la asamblea! Revista de Higiene y Sanidad Veterinaria. 1912; 2: 509-510. 
creation of this inspectorate (considered the elite of the profession) not only provided their holders with higher salaries that were directly paid by the State, but also departed from a traditional pattern of professional practice that was based on an economic dependence on councils (which were not always famed for paying properly, and in some cases, did not pay at all) and frequently subjected to the arbitrary nature of local policy. Although these inspectors only represented a tiny part of the veterinary profession as a whole ${ }^{7}$, they acquired special importance due to their condition as paradigms of a professional conquest, and to their influence over the rest of the profession as a result of their easy access to professional journals.

These reformers, which also included lecturers at the five schools of veterinary science (Madrid, Santiago de Compostela, Córdoba, Zaragoza and León) and some veterinarians from military and municipal backgrounds, came up with an ambitious modernisation plan, the main objective of which was to adapt to the scientific changes of the day and in which the concepts developed in the laboratory, especially microbiology, assumed strategic importance. To achieve this aim, the first thing was to spread a discourse linking scientific productivity to progress and improvements in the profession - no an easy task as it was not possible to make full use of many great bacteriological advances for diagnostics and therapeutics until decades later ${ }^{8}$. Moreover, these supposed improvements took a long time to become accepted by Spanish veterinarians since they clashed with the

7. According to a study published in 1911, there were 4,946 veterinary surgeons (4,544 around the 49 provinces, 63 inspectors of livestock hygiene and veterinary health, 37 teachers from the five schools, 205 military vets and 97 students that had finished their studies in the previous year). According to an announcement in a professional journal, this was the first statistics of this kind in Spain. Veterinarios españoles. Revista Veterinaria de España. 1911; 6: 117-118.

8. One exception would be tuberculin, which was available from the end of the nineteenth century. In Spain, because there was no legal obligation to use this diagnostic test, it was not applied systematically in practice until the second half of the twentieth century, coinciding with the launch of the first campaigns to eradicate bovine tuberculosis; Gutiérrez García, José Manuel. Regulación del uso de la tuberculina a través de la legislación de la primera mitad del siglo XX. In: Libro de Actas del XI Congreso Nacional de Historia de la Veterinaria. Murcia: Asociación Murciana de Historia de la Veterinaria; 2005, p. 283-286. 
reality of the profession, marked by tough working conditions, and the vet having low social esteem ${ }^{9}$.

The certainty that laboratory medicine and the bacteriological paradigm constituted the way for undertaking a science-guided transformation of veterinary profession was adjusted to the principles that prevailed in Spanish society in the early twentieth century. In fact, scientific activity had begun to enjoy an unprecedented social and institutional backing, as it was considered to be one of the ways by which the nation could be regenerated. This tendency was especially notable following the «Disaster» (a term used to refer to the 1898 Spanish-American War which led to Spain to lose Cuba and other American and Asian colonies), one of the causes of which was perceived to be the scientific and technological backwardness and the absence of a national science. In this context, real adaptation to these changes became an essential requirement in order to claim a place for veterinarians in the hierarchy of social groups and to defend their collective interests against other groups that were perceived as a threat against their professional conditions and aspirations ${ }^{10}$.

9. To understand the nature of the veterinary profession in the early twentieth century, it would be useful to possess statistics that can tell us how its labour market was structured. If we consider historiographic contributions regarding the territorial distribution of other health professions, it can be deduced that most veterinarians did their work in rural environments. In this respect, see Villacorta Baños, Francisco. Profesionales y burócratas. Estado y poder corporativo en la España del siglo XX, 1890-1923. Madrid: siglo veintiuno editores; 1989, p. 189-198. This hypothesis is reinforced by the traditional system of municipal contracting that prevailed in Spanish administration for centuries and guaranteed the presence of different experts in the area where they were contracted. A study that focuses on animal medicine in Catalonia in the eighteenth century shows that this contractual formula made it possible to establish albéitares (the word albéitar, of Arabic origin, refers to a person that cured animals before the term veterinario came into popular usage), along with doctors, surgeons and pharmacists in small towns and also shows how they were guaranteed a certain financial security as their contracts were mainly for three or four years. Zarzoso, Alfons. Medicina para animales en la Cataluña del siglo XVIII: una práctica médica plural. Asclepio. 2007; 49: 101-130.

10. For the bibliography that highlights the regenerative impulse that Spanish science underwent following the «Disaster», see: González de Pablo, Ángel. El Noventayocho y las nuevas instituciones científicas. La creación del laboratorio de investigaciones biológicas de Ramón y Cajal. Dynamis. 1998; 18: 51-79. Barona Vilar, Josep Lluis. Juan Negrín (1892-1956) y la investigación experimental en el laboratorio de fisiología de la junta para ampliación de estudios. Dynamis. 1990; 10: 255-273. More information on the risk of the nonchalant use of the term science in historiographic studies of the professionalization processes in: Shortt, S.E.D. Physicians, science, and status: issues in the professionalization of Anglo-American medicine in the nineteenth century. Medical History. 1983; 27: 51-68. 


\section{The role of veterinary medicine in public health in Spain: A conflict of professional interests}

The arrival of the twentieth century brought far-reaching changes in the strategies to raise the scientific and technical profile of veterinary surgeons. Added to the need for modernisation of the profession, their responsibilities for public health were about to be rethought and extended, as microbial theory shed new light on knowledge of animal diseases, many of which were proving to be zoonotic ${ }^{11}$.

The finding that animals were the source of many human diseases created ideal conditions for a new expert - the «scientific laboratory veterinarian»- to serve public health in the event of epizootics, in day-to-day inspections of livestock entering slaughterhouses and in inspections of meat, milk and other products for human consumption ${ }^{12}$.

Various discoveries had played a part in the introduction of a generally applicable veterinary inspection service for meat, above all the identification of the parasites responsible for trichinellosis and porcine cysticercosis. The trichinellosis epidemics - so frequent during the second half of the nineteenth century - had set alarm bells ringing among the public and made a decisive contribution to organising meat inspections in line with more scientific criteria. These outbreaks were so serious that they used to attract great publicity in the newspapers and prompted the Spanish authorities and consumers alike to concede the prophylactic value of veterinary inspection. These features led to the publication of the Royal Order of 9 October 1883 which, for the first time, introduced the obligation to submit the pork for public consumption to trichinoscopic examination ${ }^{13}$.

11. Cordero Campillo, Miguel. Desarrollo histórico de la medicina preventiva. Barcelona: Crin Ediciones; 1996.

12. For details on bovine tuberculosis, see: Gutiérrez García, José Manuel. Meat as a vector of transmission of bovine tuberculosis to humans in Spain: a historical perspective. Veterinary Heritage. 2006; 29 (1): 25-27. Gutiérrez García, José Manuel. Milk as a vector of transmission of bovine tuberculosis to humans in Spain: a historical perspective. Veterinary Heritage. 2006; 29 (2): 41-44.

13. Sanz Egaña, Cesáreo. Historia de la veterinaria española. Madrid: Espasa-Calpe; 1941, p. 393. One of the cases that gained the greatest repercussion was the outbreak of trichinellosis in the Valencian town of Villar del Arzobispo, in 1877, where the fear unleashed by the first deaths led to the prohibition of the consumption of pork and slaughterhouse products. This epidemic led to a major monograph on the disease: De las trichinas y de la trichinosis en España, in which doctor Antonio Suárez Rodríguez sought to calm the population by relating 
But now municipal veterinary inspections, traditionally centred on parasitosis, had behind them a far broader professional code that was shaped by the discoveries at the schools of Louis Pasteur and Robert Koch and by the new discipline of bacteriology. Moreover, this consolidation of the veterinarians' role in the health sector was to contribute to strengthening their professional interests, since it would guarantee their monopoly over questions concerning food inspection and put them in a better social position ${ }^{14}$.

Nevertheless, this assertion of the role of the veterinary surgeon in public hygiene clashed with the supremacy medical circles held in the prestigious world of microbes ${ }^{15}$. This circumstance led the Spanish authorities to consider it perfectly natural to seek a medical opinion on all issues relating to livestock farming ${ }^{16}$.

Accordingly, medical doctors were those who decided, for instance, whether or not to subject cattle from Málaga to the tuberculin test ${ }^{17}$. Another highly significant feature is that in 1902 the «Ministerio de la Gobernación» (Ministry of Public Administration) based its decision to reject the use of tuberculin in dairy cows in Logroño on the opinion of the members of the Royal Academy of Medicine ${ }^{18}$.

the facts about Villar del Arzobispo and publishing a series of instructions about the origin and treatment of this parasitosis. Following this epidemic, the Valencia City Council ordered an inspection of all sacrificed animals in the General Slaughterhouse in the city. Báguena Cervellera, María José; Gener Galbis, Carlos. La triquinosis en la España del siglo XIX a través de la obra de Antonio Suárez: De las trichinas y de la trichinosis en España. Medicina e Historia. 1984; no 3.

14. According to a research line proposed by theoreticians and historians of professions, a crucial aspect of professionalisation processes combines the quest for social position and prestige with the struggle to consolidate a market. See: González Leandri, Ricardo. Las profesiones: entre la vocación y el interés corporativo. Fundamentos para su estudio histórico. Madrid: Catriel; 1999, p. 103.

15. Microbiology made a fundamental contribution to the enormous prestige which medicine had acquired at the turn of the twentieth century. See: Porras Gallo, Ma Isabel. La lucha contra las enfermedades «evitables» en España y la pandemia de gripe de 1918-19. Dynamis. 1994; 14: 159-183.

16. Gutiérrez García, José Manuel. La tuberculosis bovina como zoonosis en la España contemporánea (1850-1950) [doctoral thesis]. Universidad Autónoma de Barcelona; 2003, p. 180-194.

17. López Sánchez, José. Patología bovina. El diagnóstico de la tuberculosis por la tuberculina. Málaga: Imp. Fin de Siglo; 1900, p. 6-7.

18. Farreras Sampera, José; Sanz Egaña, Cesáreo. Manual del veterinario inspector de mataderos, mercados y vaquerías. Barcelona: Publicaciones de la Revista Veterinaria de España; 1917, vol. 2, p. 1049-1050. 
The discontent that such kind of actions provoked among veterinary surgeons was echoed in the Revista de Higiene y Sanidad Veterinaria (later renamed Revista de Higiene y Sanidad pecuarias), the principal mouthpiece of the veterinary health profession during the first third of the twentieth century ${ }^{19}$. In April 1911, the editorial at the journal's first issue stressed the need «to demonstrate to those who persist in not seeing it that we are an autonomous class and that we are prepared to battle to make sure that nobody usurps our rightful role in health and hygiene matters» 20 .

In the same year, Dalmacio García Izcara, professor at Madrid Veterinary School, criticised a Health Bill draft for granting almost absolute supremacy to medical doctors, so that it left aside and ignored pharmacists and veterinarians, even on public hygiene issues for which they held exclusive responsibility. He pointed out that this situation was unequalled in any other country and satirised that perhaps things were different in Spain and that the wisdom of the «most illustrious» medical doctors also extended to veterinary and pharmaceutical knowledge. In that case, he

19. This journal, along with the Revista Veterinaria de España (founded in 1906 as the Revista Pasteur and, as its name suggests, focused on publishing different studies related with microbiology, many of them being based on translations of foreign authors), were the media that channelled most veterinary literature in the first third of the twentieth century and that assumed the responsibility for coordinating professional claims (although the Revista de Higiene y Sanidad Veterinaria was more vindicative as regards professional affairs than the Revista Veterinaria de España). Although other publications appeared in this period, they were generally local and short-lived. It is significant to note that in these media there are no belligerent voices with the objectives of the regeneration movement. A number of features could have influenced this. Thus, the awareness of the professional crisis and the urgent atmosphere that were apparent in the pages of these journals may have led to the diffusion of a particular notion of science and progress. Also, it is easy to ascertain that the revaluation of science that took place in the early twentieth century could have helped to mould the discipline and professional development in accordance with this regenerative impulse. But there is also the possibility that these publications, in order to create a climate of opinion that favoured the reformist impetus, deliberately silenced those veterinarians that were opposed to the demands of the regenerative movement.

20. Cuatro palabras. Nuestro fin y nuestros medios. Revista de Higiene y Sanidad Veterinaria. 1911; 1: 1. In 1912, the editors of the Gaceta de Medicina Zoológica concluded an article on the situation of veterinary medicine compared with other disciplines with the eloquent cry: «Veterinary surgeons, defend yourselves against those who appropriate other people's property!». ¡Veterinarios, a defenderse!. Gaceta de Medicina Zoológica. 1912; 36: 345-347. 
concluded, it would be logical to ask the government to abolish these two disciplines in Spain ${ }^{21}$.

In defence of the good name and scientific prestige of «the class», in 1915 the board of the College of Veterinary Surgeons of Valencia, in turn, sent the Minister of Public Education a formal request to amend the statutes of the Royal Academy of Medicine of Madrid - the highest State consultative body on health matters - whose membership, in accordance with the Royal Decree of 24 November 1874, consisted of forty-eight top academics, namely forty medical doctors, six pharmacists and two veterinary surgeons. The board wished to emphasise that the scientific progress made by veterinarians over the last few years made it essential to increase their representation in this Academy to make sure that their valuable knowledge was taken into account on those public health and hygiene issues that required their cooperation. For the same reason, the board also proposed amending the regulations on the district Royal Academies of Medicine (of which there were a total of ten, governed by the Royal Order of 14 May 1886), which expressly stipulated that they should be made up of eight doctors of medicine, or a fraction of that number, one pharmacist and one veterinary surgeon ${ }^{22}$.

According to veterinary professional journals, doctors were trying to turn animal medicine into a minor branch of human medicine.Vets' apprehension has bequeathed us many written arguments about the inherent functions of each discipline among health professions ${ }^{23}$. Their uneasiness,

21. García Izcara, Dalmacio. Report by the Official College of Veterinarians of the province of Madrid to the Senate Commission hearing the draft Health Bill. Revista de Higiene y Sanidad Veterinaria. 1911; 1: 87-97.

22. Los colegios actúan. Revista de Higiene y Sanidad Veterinaria. 1915; 5: 765-775.

23. Struggles due to professional interests among doctors, pharmacists and vets were very common in the course of the institutional development of science in Spain at the beginning of the twentieth century and came to play an important role in planning, establishing and developing the Instituto de Sueroterapia, Vacunación y Bacteriología de Alfonso XIII. See: Porras Gallo, Ma Isabel. Antecedentes y creación del Instituto de Sueroterapia, Vacunación y Bacteriología de Alfonso XIII. Dynamis. 1998; 18: 81-105. A similar situation occurred in the British Isles, where medical circles tried to gain access to the field of animal diseases. To this end, doctors argued that illnesses unleashed the same processes in humans as in animals and, occasionally, were transmitted from one to the other. They pointed to physiologists who carried out vivisections on animals to investigate human bodily functions and to bacteriologists and pathologists, who used animals instead of humans in their laboratory studies. They also underlined that rabies and anthrax were two zoonotics, as Pasteur and Koch had shown, that anti-diphtheria serum was obtained from horses and smallpox vaccine from 
which was echoed more or less loudly throughout the 1910s, provides the background against which the aspirations of veterinary surgeons to have a role as experts at the highest level must be set. They placed great expectations on the laboratory as the tangible physical space where veterinary medicine could be given the authority conferred by experimental medicine and where a number of scientific questions could be debated on an equal footing with other health professions enjoying social recognition. In the final analysis, the laboratory became a place to build the veterinary medicine «we dream of, namely refined, elegant, gentlemanly, aristocratic and scientific» 24 .

\section{The laboratory and the reinvention of veterinary medicine in the cognitive order}

Although laboratory-based scientific activity occupied a prominent position in a broad range of fields, the emergence of bacteriology was the crucial factor which triggered the reform of veterinary medicine. The microbiological revolution at the end of the nineteenth century gave birth to a complex body of doctrine which was to mark the start of a new era in studying and controlling infectious animal diseases ${ }^{25}$.

In this context, laboratory science took on strategic relevance as a means of transforming animal medicine into a modern discipline and of raising the intellectual, economic and social standing of the profession ${ }^{26}$.

calves, and that bovine tuberculosis could be transmitted to humans. See: Woods, Abigail. A manufactured plague: the history of foot-and-mouth disease in Britain. London: Earthscan; 2004, p. 76-77.

24. Velasco, Nicéforo. Castellanos y leoneses ¡A la asamblea! Revista de Higiene y Sanidad Veterinaria. 1916; 6: 676-678.

25. Wilkinson, Lise. Animals and disease. An introduction to the history of comparative medicine. Cambridge: Cambridge University Press; 1992.

26. The discourses that promoted the cause of laboratory-based veterinary science operated mainly from a theoretical and rhetorical, rather than practical, perspective. Consequently, these texts, of a persuasive nature, do not provide information on the magnitude of the presence of veterinarians in laboratories (everything suggests that this presence was discrete), or of what they did in them. However, the contrast between the publications that highlighted the virtues of bacteriological science and the lack of sources validating their practical applications, seems to suggest that this knowledge was basically used as an «ideal», as a necessary theoretical stage for including vets in the emerging national science community. An example of the partisan use of a specific interpretation of the concept of science can be found in the work 
Guaranteeing non-discrimination against vets in laboratories and legitimising their full right to access to senior executive posts was therefore one of the routes to achieve the desired reinvention of veterinary medicine. In an article published in 1912, Juan Monserrat, provincial livestock hygiene and veterinary health inspector at Cádiz, criticised the regulations of this Andalusian city's municipal laboratory for relegating vets to minor positions, not allowing them entry in the same way as other specialists, and not considering them as suitable for office as director or even head of section. He added that there was not even a veterinary surgeon in charge of veterinary services, despite the fact that all the other departments were headed by specialists from the relevant discipline. Monserrat, who stressed his love for veterinary medicine and how much he hoped that it would be elevated, wrote a protest letter to the civil governor, in his capacity as president of the provincial health board, and the latter agreed to amend the regulation in order to establish equal opportunities between all specialists ${ }^{27}$.

To attain this regenerationist ideal, both individual effort and the driving force of a whole group were needed. For example, on the occasion of the third national anti-tuberculosis congress (San Sebastian, 1912), the professional journals stressed the importance of the veterinary section of this event and how this had demonstrated that, armed with science, the laboratory and the clinic, «our class» could and must occupy a prominent position in «medical tournaments» 28 .

The knowledge generated in the laboratory — specific and intelligible only to experts - was rapidly used by the advocates of reform of veterinary medicine to distance themselves from various kinds of intruders who were giving rise to unfair competition ${ }^{29}$. In fact, no other topic had generated so

by John Harley Warner on the conflict maintained in the USA between the followers of two medical currents: the defenders of clinical empiricism and those supporting the therapeutic possibilities of experimental physiology. This author reveals how the latter basically adhered to a new ideal of science (with few therapeutic achievements until then) which seemed to lead to the future transformation of medicine into a basic applied science. Harley Warner, John. Ideals of science and their discontents in late nineteenth-century American medicine. Isis. 1991; 82: 454-478.

27. Monserrat, Juan. Un aplauso a la junta provincial de sanidad de Cádiz. Revista de Higiene y Sanidad Veterinaria. 1912; 2: 147-151.

28. Resultados de un congreso. Alientos y esperanzas para el porvenir. Revista de Higiene y Sanidad Veterinaria. 1912; 2: 299-300.

29. The degree of complexity of the knowledge handled has been a frequent argument in the struggle of professions against intrusionism. For details of the speciality of medical radio- 
many comments as intrusionism, a constant concern among veterinarians for centuries. This was mainly seen in the field of farriery, but also in that of clinical assistance where intrusionism led to loss of income and of professional prestige. A multitude of surviving documents and the legislation adopted to put an end to it prove that this unfair competition existed ${ }^{30}$.

Some authors considered that intrusionism was partly due to the academic training and conduct of the vets themselves. In 1916 Felipe Romero Hernández, a vet from Villafranca de la Sierra (Ávila), said that the principal cause was people like a colleague who, rather recently, had left school with no scientific training and fondly thinking that he was the best farrier in the village, «with no collective education, peddling his professional honour among scoundrels and the disinherited, godfather of intruders and quacks, with no more loves and no more ideals than the forge and the horseshoe». In a markedly positivist discourse, he stressed that this «intruder with a diploma» knew nothing about modern veterinary medicine so that it was necessary to treat his brain with laboratory science in order to turn him into a veterinary surgeon versed in the struggle «not against these hapless

therapy, see: Medina Doménech, Rosa María; Rodríguez Ocaña, Esteban. Profesionalización médica y campañas sanitarias. Un proceso convergente en la medicina española del primer tercio del siglo XX. Dynamis. 1994; 14: 77-94. The official regulation of the exercise of animal medicine, which took place in Spain from the Renaissance onwards (first with the figure of the albeitar and later the veterinario, or veterinary surgeon), did not prevent the appearance of other resources to deal with animal sicknesses (farriers, people skilled in curing animals, castrators, etc.). Nevertheless, the criterion of legitimacy on the basis of the qualification and legal recognition of this professional activity in the framework of the Crown's economic institutions, circumscribed, from the legal point of view, this area of action to the authority of the albéitar-veterinary surgeon. This circumstance could have played an important role in the struggle to displace other competitors in the world of animal medicine, regardless of the skill that these had demonstrated. A consequence of this was that the representatives of 'other' possibilities for cure were unable to organise themselves into defined categories (with the exception of farriers, who were also officially recognised). To work as an albéitar, the aspirant had to be subjected to a double examination (theoretical and practical). If the test was successfully passed, they were awarded a licence that recognised their entitlement to legally work in animal medicine. There were examining tribunals all over the territories under Spanish Monarchy, controlled by guilds, except the Real Tribunal del Protoalbeiterato, with its headquarters in Madrid, whose examiners were personally designated by the King. This form of access to the condition of being an expert in animal medicine remained valid for more than three and a half centuries (from the late fifteenthth century to the mid nineteenth century, when the albéitares were displaced by the pressure exercised by those entering the labour market qualified as veterinary surgeons). Sanz Egaña, n. 13.

30. Sanz Egaña, n. 13, p. 313. 
intruders with whom he is squabbling today, but with those high-ups whom he knows only by hear-say» - a clear allusion to doctors ${ }^{31}$.

This kind of self-legitimising discourse considered the 1912 reform of the syllabus (Royal Decree of 27 September 1912) as a undeniable proof of the regeneration of veterinary medicine and as a guarantee of its scientific nature. This reform replaced the syllabus which had been the norm since 1871 and, although it kept the length of studies at five academic years, it introduced, as the principal innovation, subjects related to bacteriology. As the Royal Decree itself stated:

«since then [1871], and especially since Pasteur and his disciples started their immortal work, the nature, scope and applications of veterinary medicine have changed deeply and totally. Today no practitioner can be only a clinician, but also a researcher who has been solidly and extensively prepared at the classroom and the laboratory» ${ }^{32}$.

This idea of progress linked with the level of training is clearly reflected in the article «El resurgimiento de la veterinaria española» (The resurgence of veterinary medicine in Spain), published in 1915. Its author, a pupil of the Zaragoza school, compared the vets of yesteryear who, like his father, were «badly dressed and even worse educated, with a bowler hat and red boots, callous hands, submissive and obedient» with the contemporary «veterinary surgeons of the laboratory, of first-rate clinical practice, of livestock and food inspections, of slaughterhouses, the guardians of public health» who were «well dressed and even better educated, in a worthy position in society and in possession of an enormous stock of the most difficult, highly humanitarian knowledge; that is, true men of science» ${ }^{33}$.

In the same year, at the time when the earliest treatise on veterinary bacteriology written by a Spanish veterinarian (Resumen de bacteriología especial para prácticos y estudiantes by the livestock hygiene and veterinary health inspector for the province of Barcelona, Cayetano López López) was published, Félix Gordón Ordás, the provincial livestock hygiene and

31. Romero Hernández, Felipe. El cáncer de la veterinaria. Revista de Higiene y Sanidad Veterinaria. 1916; 6: 771-774.

32. Royal Decree on the reorganisation of veterinary schools. Gaceta de Madrid, no 272, 28 September 1912: 720.

33. Garreta Zanuy, Ángel. El resurgimiento de la veterinaria española. Revista de Higiene y Sanidad Veterinaria. 1915; 5: 848-849. 
veterinary health inspector of Madrid, highlighted the need to rebuild the profession with «young men hungry for scientific truth» and, to this end, appealed to the progressive spirit of the new veterinary surgeons, to this batch of illustrious and hard-working professionals whose work had succeeded in creating, in the public conscience, new consideration for veterinary medicine. With this treatise Gordón, who was also the editor of the Revista de Higiene y Sanidad Veterinaria, inaugurated a collection entitled Biblioteca del veterinario moderno (Library of the modern vet). By using presentist rhetoric, he stressed that López López's book was born from the desire to serve the scientific needs of the day and that it had appeared in the intellectual world of veterinary medicine when the struggle was hardest, «at a time when many of the most eminent in past generations would open themselves to ridicule» ${ }^{34}$.

A regenerationist drive that was most clearly expressed by the numerous proposals made to change the name of the profession («livestock engineering» was the most widely bandied). This demand, which was also voiced in connection with the above-mentioned reform of the syllabus, was finally rejected by the Minister for Public Education and Fine Arts, Santiago Alba y Bonifaz ${ }^{35}$.

In the field of meat inspection too, the laboratory became an ally for promulgating a reform of veterinary practice and for giving the profession a scientific authority. In 1916 Tomás Rodríguez, professor at Santiago School of Veterinary Medicine, said that correct procedures in slaughterhouses required broad knowledge of pathological anatomy and a well-equipped laboratory. This author considered that rigorous examination to determine whether meat was fit for human consumption required cutting the samples into the thinnest slices for pathological examination and colouring them appropriately, as if they were pages of a book which only veterinary sur-

34. Gordón Ordás, Félix. Autores y libros. Leyendo papel impreso. Revista de Higiene y Sanidad Veterinaria. 1915; 5: 241-242. Although the publishing market already included books on veterinary bacteriology thanks to translations of foreign works, and also the handbook Elementos de Microbiología para uso de estudiantes de Medicina y Veterinaria, by Spanish doctor Luis del Río y Lara, it was the fact that Cayetano was a veterinarian that was particularly highlighted in this campaign for the modernisation of the profession. On the contributions to veterinary science by Luis del Río y Lara, see: Báguena Cervellera, María José. Luis del Río y Lara y la constitución de la microbiología médica en España. Asclepio. 1988; 40: 375-393.

35. Cordero Campillo, Miguel. La universidad de León. De la escuela de veterinaria a la universidad. León: Editorial Everest; 1983, p. 115-116. 
geons were capable of reading, and then deciding on the correct course of action. In a discourse which linked epistemology to authority, he argued that this way of working, combined with the wealth of scientific knowledge they possessed, was what really differentiated veterinary surgeons from the «slaughtermen and council employees, such as weighers, markers, cleaners, etc.», who perfectly knew from experience the four typical types of organ injury:

«And if we need not know more than them, our role would be completely ridiculous. If, instead, we do not make do with this already common knowledge, but want something more, then the situation is quite another. Then a great deal of laboratory work is needed» ${ }^{36}$.

Consequently, laboratory provided a material and cognitive base for an elitist epistemology and for reformulating veterinary medicine into a body of privileged knowledge accessible only to a small proportion of qualified professionals ${ }^{37}$. Tomás Rodríguez added that, in order to enjoy autonomy, it was indispensable for veterinary surgeons to have ties with a laboratory by working alongside a doctor, chemist or scientist, and that this was the only way that:

«we would demonstrate to these professionals that, even though it is true that some vets are no more than farriers (there is always one rotten apple), it is no less true that there are quite a number of older veterinary surgeons and many young ones with such full scientific baggage who can very well stand side by side with others who had the good fortune to choose professions held in greater esteem and no more» ${ }^{38}$.

Not only was it necessary to acquire a scientific base, but also veterinary surgeons had to surround themselves with a scientific aura to raise

36. Rodríguez, Tomás. En los laboratorios de higiene, ó fuera de ellos. Revista de Higiene y Sanidad Veterinaria. 1916; 6: 136-141 (137).

37. John Harley Warner pointed out that acceptance of the laboratory as the basis for medical practice in the USA was due to the perception that it generated a type of knowledge which bore authority. Harley Warner, John. The fall and rise of professional mystery. Epistemology, authority and the emergence of laboratory medicine in nineteenth century America. In: Cunningham, Andrew; Williams, Perry, eds. The laboratory revolution in medicine. Cambridge: Cambridge University Press; 1992, p. 110-141.

38. Rodríguez, n. 36, p. 140. 
their reputation. Under the title Cómo se hace veterinaria (How to practice veterinary medicine), Pablo Martí Freixas, the official veterinary surgeon in Terrassa, highlighted the great interest aroused by the histology courses given by the professor of veterinary medicine Abelardo Gallego at Barcelona Biology Society. Their fame had attracted so many doctors and vets that these lectures had to be repeated in a second series. In the opinion of Martí Freixas, Gallego had succeeded, in just fifteen days, in taking the concept of veterinary medicine to a higher plane than hundreds of veterinary practitioners would have achieved with countless years of work. The same author also recognised the significance of the research into bacteriology by two colleagues, Ramón Turró and Joaquín Ravetllat, two scientists who were managing to «create space for us, when it seemed that we were allowed to go nowhere» ${ }^{39}$.

This scientific and technical rise in status also needed to be reflected directly in the veterinary surgeon's personal style. This parallel would only confirm the identification of veterinary surgeons with the dominant classes of society. In the view of Gordón Ordás, the path to modernisation of the profession necessarily passed through modernisation of the vets themselves, who had to conduct themselves properly, firstly as good practitioners and then in their manners. Accordingly, modern veterinary surgeons, as men of science, should be required to improve their public image as an intellectual professional to the detriment of the more manual aspects of the profession and should have a general culture that would enable them to talk, for example, about Greek theatre, the Punic wars or the topography of Tripoli. All of this should always be accompanied by relatively elegant attire which would allow them to fraternise without stigma with the most refined classes of society ${ }^{40}$.

According to the same author, this modernisation must be likened to any other vital function: «In the same way as germination of the Malpighi layer sheds from the skin the oldest cells, which are uprooted and die, the analogous phenomenon of modernisation plays the same role in the social

39. Martí Freixas, Pablo. Cómo se hace veterinaria. La estela de A. Gallego. Revista de Higiene y Sanidad Veterinaria. 1916; 6: 911-915.

40. Gordón Ordás, Félix. Mi propaganda oral [extract from lectures in Turégano, Segovia]. Revista de Higiene y Sanidad Veterinaria. 1913; 3: 585-593. 
life. The son makes us forget the father and the disciple makes us forget the master» ${ }^{41}$.

\section{The laboratory and the reinvention of veterinary medicine in the social order}

Leaving aside the idealised image which the positivist discourses painted of the cognitive and intellectual side of the new veterinary surgeons, extensive rhetoric was also deployed in response to the desire to improve the economic and social order. Insistently used arguments stressed the scientific training of veterinary surgeons, which not only justified their economic aspirations, but also would guarantee their long-awaited ascent up the social ladder.

In 1912, Juan Arderius, president of the College of Veterinary Surgeons of the province of Girona, bemoaned that the majority of the population did not understand the value of veterinary medicine, and assumed that «it is the same today as to what it would have been before undergoing the great advances brought about by microbial doctrine». Moreover, he recalled that veterinary medicine had been the first health discipline to accept Pasteur's theory and put it into practice ${ }^{42}$.

In 1915, Gordón Ordás gave various examples illustrating the low social prestige in which vets were held and complained about how they had been rejected in society when it came to considering veterinary medicine an intellectual profession. Gordón considered that this unjust opinion of the profession was due to small-minded, uncouth practitioners of veterinary medicine, of whom just a few survived in each province and who could barely spell nor sign their name when they entered veterinary school. What is more, he added, these were the same people who still wore sandals and an apron and slung their jacket over their shoulder - disciples of professors «like one who took off his jacket and rolled up his shirtsleeves to give his pupils a practical demonstration of how to take the hammer from the forge or another who used to say, after the complete triumph of Pasteur's theory,

41. Gordón Ordás, Félix. Mi propaganda oral [extract from lectures in Burgos]. Revista de Higiene y Sanidad Veterinaria. 1915; 5: 297-300 (p. 299).

42. Arderius Banjol, Juan. La reforma de la enseñanza veterinaria. Revista de Higiene y Sanidad Veterinaria. 1912; 2: 440-445. 
that he could not get all this about microbes into his head». He added that although this state of affairs was history, it had left a deep mark on the public conscience which was difficult to erase. For this reason, he considered that the best way to sweep away this negative image was to give constant demonstrations of the opposite, which implied not only being brilliant veterinary surgeons, given that only a few people could appreciate this, but also that it was indispensable to enter laboratories, libraries, athenaeums, periodicals, political circles, and so on. He considered that this was not the time to sit and wait, but that it was necessary to show the world,

«that we are a scientific collective and that we deserve to be treated with greater respect and consideration. Because all scientific professions have two aspects: their science and the esteem in which their science is held. Just as it was not enough for Caesar's wife to be beyond reproach, but also she had to be seen to be so, for scientific professions too it is not enough to have science nor morals, but also they must be seen to have both these things. There is no need for me to tell you that veterinary medicine is an eminently scientific profession and is moral. But do people believe this to be so?» ${ }^{43}$.

In 1913, Francisco Gómez Suárez, a veterinarian from Álora (Málaga), complained that after long, difficult, costly studies, in most places vets were still not perceived as men with a university education, but as labourers whose job was to shoe animals or, at most, were empirical healers treating animal diseases. He added that this view was shared by different social groups, «from the most ignorant class, with which we have to deal every day ... to the intellectual class, the same who sat their school-leaving examinations with us and before whom we demonstrated that we were good enough to pass them». He gave a number of examples, such as the case of a colleague in a village in the Levante region who had fallen in love with «a beautiful, educated young lady of fairly high social status. As soon as the relationship between the two became known, the villagers were astounded and excitedly commented that Miss X, who had rejected doctor A and rich merchant $\mathrm{B}$, had yielded to the amorous advances of Mr Nobody,

43. Gordón Ordás, Félix. Mi propaganda oral (extract from lectures in Barcelona). Revista de Higiene y Sanidad Veterinaria. 1913; 3: 831-844 (p. 840-841). In the same article, Gordón stressed the high social standing which veterinary medicine had gained in Germany and France, which had made it possible for veterinary surgeons such as Schütz and Jean-Bautiste Chauveau to hold the presidency of the Academy of Sciences. 
the vet». In any event, this author showed how the discourses in favour of the need for change and modernisation of veterinary medicine clashed with the everyday reality experienced by the professionals in the field of whom, according to his own estimates, $80 \%$ still spent all their working hours shoeing horses. To put an end to this state of affairs, he proposed that veterinary surgeons should delegate these tasks once and for all so that they could build up their mission as men of science, both in health and in livestock activities. He considered it fundamental that the population must be capable of appreciating the enormous difference between the farrier and the veterinary surgeon which, according to the author, was the same as between the doctor and the barber, or between the agronomic engineer and the market-gardener. Finally, he said that the logical culmination of this metamorphosis was, first and foremost, to replace the anvil, hammer and pliers by the instruments pertaining to the laboratory and modern science: microscopes, clinical thermometers, syringes, etc. ${ }^{44}$.

However, in 1916 Enrique de Beitia, the municipal veterinary surgeon in Bilbao, considered the chances of finding one of these mustily clad old-school vets highly unlikely. Nevertheless, he considered that even if such a depressing figure were to reappear somewhere or other, he would have nothing in common with the modern veterinary surgeon, with very different training, dressed up for high social representation and capable of fraternising with the most distinguished members of society and of heading the most refined laboratories ${ }^{45}$.

Judging from other sources from the same time, this optimistic diagnosis was far from the truth. As Gordón Ordás wrote in 1915, «Today if a veterinary surgeon triumphs, it is despite being a vet; we must aspire to a situation where anyone who rises from among us tomorrow will do so precisely because of being a vet». Gordón considered that much of the blame lay with the professionals themselves, both those at the top, who scoffed about microbes because they had not seen any running around on the streets, and the more modest at the bottom, who were deaf to the new music and did no more than forge and fit horseshoes. The same author called for imitating colleagues in other countries in Europe (France, Ger-

44. Gómez Suárez, Francisco. El veterinario en sociedad. Revista de Higiene y Sanidad Veterinaria. 1913; 3: 581-584.

45. Beitia, Enrique. El veterinario futuro. Revista de Higiene y Sanidad Veterinaria. 1916; 6: 221 223. 
many, Russia, and so on), swept along by a powerful tide of modernisation, centred on disseminating the doctrines of Pasteur and calling for laboratories, peering down microscopes and preparing vaccines. What is more, according to Gordón, only if they earned the title of men of science could they demand wages commensurate with tasks of this nature 46 .

Nevertheless, the quest for this ideal had borne some fruit. The most tangible and celebrated example was the Catalan veterinary surgeon Ramón Turró, who rose to the post of director of the Municipal Laboratory of Barcelona, one of the most influential scientific institutions in Spain ${ }^{47}$.

The staunch vindication of the central role of laboratories as an unbeatable opportunity to transform the identity of veterinary medicine weighed down by past practice and by its low social prestige also extended to the components associated with the new temples of science, namely Petri dishes, vaccines, serums and so on -all the tools to seek, measure and quantify the causes of illnesses, and to prevent them from appearing and spreading. These methods, capable of «cracking Nature's secrets» ${ }^{48}$, took on an ever greater role and, finally, became the most tangible signs of the transformation of the profession. In 1915, Francisco Souza, a veterinary surgeon from Córdoba, underlined how indispensable instruments related to scientific progress had become, such as the «god Microscope» which revealed a minute world incomparably more fearful than the fullsized world ${ }^{49}$.

Although discourses in favour of using the laboratory as a platform to raise the prestige of the profession proliferated during the 1910s, there was no unanimity on the means to be used to achieve this objective. Cesáreo Sanz Egaña, livestock hygiene and veterinary health inspector of Málaga, considered that a radical change of strategy was required in order to gain greater social prestige. According to Egaña, up until now the efforts to lend weight to the task of veterinary surgeons had focused on the services which they provided to public health, but it sufficed to read all the health legislation

46. Gordón Ordás, Félix. Mi propaganda oral [extract from lectures in Guadalajara]. Revista de Higiene y Sanidad Veterinaria. 1915; 5: 775-778.

47. For further information on the management of Ramón Turró as director of the Municipal Laboratory of Barcelona, see: Roca Rosell, Antoni. Història del Laboratori Municipal de Barcelona, de Ferran a Turró. Barcelona: Ajuntament de Barcelona; 1988.

48. Rodríguez, Tomás. Por última vez. Revista de Higiene y Sanidad Veterinaria. 1916; 6: 679-680.

49. Souza, Francisco. Lo que tú no hagas, ni Dios te ayuda. Sobre una protesta. Revista de Higiene y Sanidad Veterinaria. 1915; 5: 760-762. 
to see that the veterinary surgeon always featured as a doctor's assistant. Consequently, the time had come for veterinary surgeons to regain their freedom and put livestock activities before public health concerns ( $«$ the opposite of what we have been practising and promoting up until now») and to centre their work on the needs of breeders and livestock farmers, bringing a ray of science to the stable and to the meadow ${ }^{50}$.

Javier Prado, livestock hygiene and veterinary health inspector of the province of Orense, considered that reinvention of veterinary medicine must be achieved by winning the posts with the highest pay, greatest prestige and the brightest lustre, for example as technical director for all livestock matters and «scientific research» ${ }^{51}$.

In addition to clinical practice, public hygiene and promotion of agricultural production, the far-reaching revolution triggered by the Pasteur era demonstrated that research was also part of the definition of the new veterinary medicine. This aspiration could be achieved by giving unconditional support to every line of research undertaken by a professional in animal medicine. The need to find key names to take as references in this domain explains the exceptional coverage given in the veterinary press to the experimental work on tuberculosis by Joaquín Ravetllat, a tangible example of this new generation of veterinary surgeons who were highly trained and fully devoted to scientific research ${ }^{52}$.

Another recurrent theme was the uneasiness caused by low salaries. The demands for improvements of this aspect were also based on the scientific nature of the activities performed by the profession. In response to an outbreak of trichinellosis in Algar (Murcia) in 1913, which finally led to various deaths and the imprisonment of the municipal vet, Luis Saiz, the inspector of markets and fish markets of San Sebastián, said that before a vet could guarantee public health, two fundamental conditions must be

50. Sanz Egaña, Cesáreo. Acción pecuaria. Revista de Higiene y Sanidad Veterinaria. 1913; 3: 732734.

51. Prado, Javier. Intereses profesionales. La clasificación de partidos veterinarios. Revista de Higiene y Sanidad Veterinaria. 1913; 3: 751-753.

52. The veterinary press helped to improve the image of Ravetllat as a moderniser of the profession. The press launched an impassioned movement to support Ravetllat that was intended to give him the means to continue his scientific research. For further information on the Ravetllat case, see: Gutiérrez García, José Manuel. El impacto del laboratorio en la renovación de la veterinaria española: el caso Joaquim Ravetllat i Estech (1871-1923). Medicina e Historia. 2007; no 4. 
met, namely to provide the appropriate material for carrying out these inspection tasks, and to improve pay, commensurate with the scientific nature of the duties ${ }^{53}$. An anonymous note published in 1914 stressed that just as important as the micrographic laboratory was the micrographic vet's «bread and butter» and that before demanding responsibility and competence from the veterinary health services, they had to be given the means and remuneration ${ }^{54}$. This climate could have influenced the decision taken in the same year by pupils in the fifth year of the Zaragoza Veterinary School not to take up posts which were underpaid ${ }^{55}$.

\section{Conclusions}

In the light of the foregoing, it can be said that at the turn of the twentieth century, a group of veterinary surgeons concerned about the future of a profession in decline and stuck in routine identified and called for new professional pathways with the objective of laying the foundation for a «new» discipline. To meet these demands for modernisation, they subscribed to a positivist mentality, drawing on the value of laboratory medicine and the new bacteriological paradigm to accentuate the changes which differentiated them from and raised them above their predecessors in the history of this profession. A discipline was developed which also led to conflicts of interest among the different health professions and placed special emphasis on exhibiting the credentials of a new professional prototype, destined to occupy a prominent position in science and society.

By way of conclusion, this paper has dealt with the process of slow, inexorable change and modernisation on which veterinary medicine in Spain embarked in the first few decades of the twentieth century, not by analysing what the profession was at a particularly critical point in its history, but by looking in greater depth into what it was aiming to be, under the new bacteriological paradigm.

53. Saiz, Luis. La triquinosis. Al Sr. ministro de la gobernación. Revista de Higiene y Sanidad Veterinaria. 1914; 4: 29-32.

54. Realidades y sospechas. Las inspecciones municipales de sanidad. Revista de Higiene y Sanidad Veterinaria. 1914; 4: 33-36.

55. Entre estudiantes. Una idea generosa. Revista de Higiene y Sanidad Veterinaria. 1914; 4: 54-56. 